\title{
Uji Organoleptik Daging Persilangan Ayam Kampung Broiler dengan Kepadatan Kandang yang berbeda
}

\section{Organoleptic Test of Kampung Broiler Chicken Crossbreeding with Different Density}

\author{
Andi Fausiah ${ }^{1}$, Andi Tenri Bau Astuti Mahmud ${ }^{2}$ dan Samsu Alam Rab ${ }^{\mathbf{3}}$ \\ ${ }^{1}$ Program Studi Peternakan, Fakultas Ilmu Pertanian, Universitas Al-Asyariah Mandar \\ Jalan Budi Utomo No 2, Manding \\ E-mail: andifausiah31@gmail.com \\ ${ }^{2}$ Program Studi Peternakan, Fakultas Ilmu Pertanian, Universitas Al-Asyariah Mandar \\ Jalan Budi Utomo No 2, Manding \\ E-mail: anditenribauastuti@gmail.com \\ ${ }^{3}$ Program Studi Peternakan, Fakultas Ilmu Pertanian, Universitas Al-Asyariah Mandar \\ Jalan Budi Utomo No 2, Manding \\ E-mail: samsualamrab@gmail.com
}

\begin{abstract}
ABSTRAK
Penelitian ini bertujuan uji organoleptik daging Ayam kampung broiler dengan kepadatan kandang yang berbeda. Hasil yang didapat pada penelitian organoleptik yaitu dengan hedonic dan mutu hedonik adalah Penampilan umum hedonik dan mutu hedonik penilaian panelis memiliki rata-rata scor 3 (utuh sedikit menarik). Untuk penilaian tekstur rata-rata skor tekstur 3 (agak kasar), hal tersebut tidak berbeda nyata $(P>0.05)$. Pada pengujian warna pengujian hedonik memberikan pengaruh yang nyata $(P<0.05)$, sedangkan pada pengujian mutu hedonik tidak memberikan pengaruh pada perlakuan. Rata- rata scor pengujian warna oleh panelis yaitu score 3 (pucat) hal tersebut di sebabkan warna suatu produk pangan merupakan daya tarik utama dan untuk uji rasa nilai rata-rata rasa daging Ayam kampung broiler memiliki rata-rata score sebesar 2,41. Kesimpulan penelitian ini adalah hasil pengujian organoleptik hedonik dan mutu hedonik terhadap persilangan Ayam kampung broiler dengan kepadatan kandang yang berbeda semua perlakuan masih berada pada kisaran score 3.
\end{abstract}

Kata Kunci : Ayam Kampung Broiler, Kandang, Hedonik dan Mutu Hedonik

\begin{abstract}
The aim of this study was organoleptic testing of native broiler chickens with different cage densities. The results obtained in organoleptic research namely hedonic and hedonic quality are the general appearance of hedonic and hedonic quality of panelists' assessment has an average score of 3 (intact is a bit interesting) ,. For texture scoring average texture scores 3 (a bit rough), it has no real effect $(P>0.05)$. In the hedonic test the color test has a significant effect $(P<0.05)$, while the hedonic quality test does not affect the treatment. Average color testing Scor color testing by panelists namely a score of 3 (pale) is because the color of a food product is the main attraction And for the taste test The average value of the taste of broiler chicken has an average score of 2.41 The conclusion of this study is the results of hedonic organoleptic testing and hedonic quality of crossbreed broiler chickens with different densities of cages, all parameters in the treatment are still in the range of score 3.
\end{abstract}

Keywords : Broiler Kampung Chicken, Cage, Hedonic and Hedonic Quality.

\section{PENDAHULUAN}

Daging merupakan bagian tubuh ternak yang telah disembelih dan layak untuk dikonsumsi daging sebagai bahan pangan yang dapat menimbulkan kepuasan atau kenikmatan bagi yang mengkonsumsinya karena kandungan gizi seperti protein hewani, air, energi, vitamin dan mineral, sehingga keseimbangan gizi untuk hidup dapat terpenuhi (Hafid, 2008).

Ayam kampung merupakan salah satu jenis ternak yang banyak digemari oleh masyarakat karena dagingnya lebih gurih dan aromanya khas. Selain itu untuk mendapatkan 
daging tersebut tidak sulit, sebab ayam kampung banyak dipelihara oleh masyarakat walaupun dengan cara yang masih sangat sederhana. Masyarakat juga sudah terbiasa mengkonsumsi ayam kampung dibandingkan dengan ayam ras, akan tetapi ayam kampung yang dipotong pada umur tua memiliki daging yang alot, sehingga memerlukan perlakuan khusus dalam proses pengolahannya, agar diperoleh daging yang empuk dan enak dimakan.

Ayam broiler merupakan salah satu sumber protein hewani yang gemar dikonsumsi oleh masyarakat. Ayam broiler memiliki pertumbuhan daging yang cepat dalam waktu relatif singkat, namun diantara serabut otot dagingnya mudah terakumulasi lemak. Menurut Yusniar dan Nilasari (2009), kandungan kolesterol dalam daging ayam broiler sekitar $200 \mathrm{mg} / \mathrm{dl}$ atau bahkan lebih, sedangkan kandungan kolesterol ayam kampung hanya 100-120 mg/dl. Keberadaan kolesterol yang tinggi pada ayam broiler sering digunakan sebagai pembatas konsumsi ayam broiler dalam masyarakat. Sebagian masyarakat merasa takut untuk mengkonsumsi ayam broiler karena dikhawatirkan dapat meningkatkan kadar kolesterol darah yang nantinya dapat menjadi faktor pencetus timbulnya penyakit aterosklerosis (Manoppo et al., 2007). Persilangan ayam kampung broiler diduga memiliki kualitas daging yang baik seperti pendapat Daryono et al. (2012) Daging ayam persilangan memiliki kualitas yang lebih baik dibandingkan ayam broiler. Penelitian ini bertujuan untuk mengevaluasi uji organoleptic persilangan Ayam kampung broiler dengan kepadatan kandang yang berbeda.

\section{MATERI DAN METODE}

Uji Organoleptik dilakukan dengan mutu hedonik dan hedonik menurut Arief et al. Tabel dibawah ini.
(2014) dengan jumlah panelis tidak terlatih sebanyak 40 orang, masing-masing panelis mendapat sampel daging dari semua perlakuan dan satu lembar kuesioner. Peubah yang diamati adalah penampilan umum, tekstur, rasa, warna dan aroma.

Penilaian organoleptik untuk uji hedonik adalah (1) tidak suka , (2) agak suka, (3) suka, (4) sangat suka dan (5) amat sangat suka. Penilaian organoleptik untuk uji mutu hedonik terdiri dari parameter penampakan umum, warna, tekstur, aroma dan rasa. Penilaian penampilan umum adalah (1) tidak utuh dan sangat tidak menarik, (2) utuh dan tidak menarik, (3)utuh dan sedikitmenarik, (4) utuh dan menarik serta (5) utuh dan sangat menarik. Penilaian warna adalah (1) sangat pucat, (2) agak pucat, (3) pucat, (4) agak cerah dan (5) cerah khas daging. Penampilan tekstur adalah (1) sangat kasar dan tidak empuk, (2) kasar, (3) agak kasar, (4)lembut dan empuk serta (5) sangatlembut dan empuk. Penilaian aroma adalah (1) sangat amis dan busuk, (2) amis dan agak busuk, (3) agak amis, (4)kurang amis dan (5) khas daging dan tidakamis. Penilaian rasa adalah (1) tidak gurih, (2) kurang gurih, (3) agak gurih, (4) gurih dan (5) sangat gurih.

\section{HASIL DAN PEMBAHASAN}

Uji organoleptik adalah penilaian penggunaan indra, penilaian menggunakan kemampuan sensorik, tidak dapat diturunkan pada orang lain. Salah satu cara pengujian organoleptik adalah dengan metode uji pencicipan yang disebut juga dengan Acceptance tests.

Uji organoleptik pada penelitian ini melibatkan 30 orang panelis untuk melakukan penilaian terhadap daging ayam KB yang disajikan. Rataan skor organoleptik hedonik dan mutu hedonik diperoleh dapat dilihat pada

\begin{tabular}{lccc}
\hline \multirow{2}{*}{ Organoleptik } & \multicolumn{3}{c}{ Kepadatan Kandang (ekor/kandang) } \\
\cline { 2 - 4 } & $\mathbf{8}$ (Ekor) & $\mathbf{1 0}$ (Ekor) & $\mathbf{1 2}$ (Ekor) \\
\hline Hedonik & & & \\
Penampilan umum & $3.11 \pm 0.03$ & $3.17 \pm 0.07$ & $3.14 \pm 0.09$ \\
Tekstur & $3.12 \pm 0.05$ & $3.06 \pm 0.36$ & $3.14 \pm 0.06$ \\
Warna & $2.27^{\mathrm{a}} \pm 0.16$ & $2.42^{\mathrm{ab}} \pm 0.15$ & $2.60^{\mathrm{b}} \pm 0.40$ \\
Aroma & $2.56 \pm 0.13$ & $2.55 \pm 0.19$ & $2.51 \pm 0.18$ \\
Mutu Hedonik & & & \\
Penampilan umum & $3.28 \pm 0.14$ & $3.28 \pm 0.19$ & $3.36 \pm 0.15$ \\
Tekstur & $3.36 \pm 0.18$ & $3.27 \pm 0.37$ & $3.46 \pm 0.25$ \\
Warna & $3.31 \pm 0.12$ & $3.42 \pm 0.15$ & $3.44 \pm 0.20$ \\
Aroma & $3.40 \pm 0.16$ & $3.32 \pm 0.41$ & $3.51 \pm 0.18$ \\
Rasa & $2.34 \pm 0.11$ & $2.41 \pm 0.22$ & $2.40 \pm 0.23$ \\
\hline
\end{tabular}

Keterangan:

Penampilan Umum: 1) tidak utuh dan sangat tidak menarik, (2) utuh dan tidak menarik, (3)utuh dan sedikitmenarik, (4) utuh dan menarik serta (5) utuh 
Uji Tektur : 1) sangat kasar dan tidak empuk, (2) kasar, (3) agak kasar, (4)lembut dan empuk serta (5) sangat lembut dan empuk

Uji Warna : skor 1 sangat pucat; skor 2 pucat, skor 3 tidak kuning, skor 4 kuning, skor 5 kuning

Uji Aroma :skor 1 sangat amis; skor 2 amis; skor 3 agak amis; skor 4; kurang amis; skor 5 tidak amis

Uji rasa : skor 1 sangat tidak enak; skor 2 kurang enak; skor 3 agak enak; skor 4 enak; skor 5 sangat enak

\section{Uji Organoleptik Penampilan Umum}

Pengujian hedonik untuk penampilan umum, penilaian panelis memiliki rata-rata scor 3 (utuh sedikit menarik), pada kepadatang kandang 8, 10, 12 Ekor scor tertinggi pada kepadatan kandang 10 ekor. Hampir sama dengan pengujian mutu hedonik penilaian panelis rata-rata scornya 3 berdasarkan pengujian uji Kruskal-Wallis menunjukkan kepadatan kandang pada ayam kampung broiler tidak berbeda nyata $(P>0,05)$ terhadap penampilan umum. Hal ini menunjukkan panelis memberikan penilaian yang baik pada daging ayam KB dan sebagian besar panelis menyukai daging bagian paha pada ayam KB.

\section{Uji Organoleptik Tekstur}

Untuk penilaian tektur pada pengujian hedonik dan mutu hedonik rata-rata scor untuk tekstur 3 (agak kasar), hal tersebut berdasarkan pengujian Kruskal-Wallis tektur persilangan ayam kampung broiler tidak berbeda nyata $(P>0.05)$ terhadap kepadatan kandang. Ukuran tekstur ditentukan oleh jumlah serabut otot, ukuran dan jumlah perimysium pembungkus. Hal-hal tersebut dipengaruhi oleh umur dan bangsa ternak (Nurwantoro et al, 2003). Lawrie (2003) menjelaskan bahwa, keempukan dan kualitas daging setelah dimasak dinilai berdasarkan kemudahan untuk dikunyah tanpa kehilangan sifat dan jaringan yang layak. Penilaian keempukan daging dapat dilakukan secara obyektif dan subyektif. Penilaian secara subyektif mengunakan metode panel test, sedangkan secara obyektif meliputi metode pengujian secara fisik dan kimia. Tiga komponen daging yang berperan terhadap keempukan yaitu jaringan ikat, serabut-serabut otot, dan jaringan adiposa. Perbedaan keempukan daging yang berhubungan dengan umur, lokasi otot, dan jenis kelamin antara lain ditentukan oleh perbedaan jumlah jaringan ikat (Soeparno,2009).

\section{Uji Organoleptik Warna}

Warna merupakan hal yang kompleks yang menjadi komponen utama dari penampilan daging atau produk unggas. Penampilan dan warna suatu makanan melibatkan organ mata dan objek (makanan) yang mereflesikan cahaya (Lyon dan Lyon 2001). Pada pengujian hedonik memberikan pengaruh yang berbeda nyata $(P<0.05)$, sedangkan pada pengujian Mutu hedonik tidak memberikan pengaruh pada perlakuan kepadatan kandang, dapat dilhat pada tabel 1. Rata- rata Scor pengujian warna oleh panelis yaitu score 3 (pucat) hal tersebut di sebabkan

Warna suatu produk pangan merupakan daya tarik utama sebelum konsumen mengenal dan menyukai sifat yang lainnya. Warna daging unggas dipengaruhi oleh beberapa faktor seperti umur, jenis kelamin, bangsa, lingkungan kandang, lingkungan pemotongan, kondisi sebelum pemotongan, kondisi pemotongan dan penyimpanan, lemak intramuskular, kandungan air daging dan pakan yang diberikan (Northcutt, 2009).

\section{Uji Organoleptik Aroma}

Aroma merupakan ciri lain yang penting dalam menilai tingkat penerimaan konsumen terhadap suatu produk pangan. Aroma berkembang pada saat daging masak, yang merupakan interaksi antara karbohidrat dan asam amino, lemak dan oksidasi ternak dan degradasi tiamin (Soeparno, 2009). Pada penelitian persilangan ayam Kampung Broiler untuk pengujian Hedonik dan Mutu Hedonik tidak memberikan perbedaan yang nyata $(P>0.05)$. Hal tersebut Uji aroma lebih banyak melibatkan indra penciuman, karena kelezatan suatu makanan sangat ditentukan oleh aroma makanan tersebut dan dapat merupakan salah satu indikator penting dalam menentukan kualitas bahan pangan. Umumnya konsumen akan menyukai bahan pangan jika mempunyai aroma khas yang tidak menyimpang dari aroma normal. Hal ini sesuai dengan pendapat Warris (2000) aroma atau bau dihasilkan dari substansi - substansi volatil yang ditangkap oleh reseptor penciuman yang ada di belakang hidung yang selanjutnya diinterpretasikan oleh otak.

\section{Uji Organoleptik Rasa}

Rasa merupakan kualitas daging sensori daging yang berkaitan dengan indera perasa. Hasil uji Kruskal Wallis rasa daging ayam persilangan kampung broiler pada kepadatan kandang yang berbeda tidak berpengaruh nyata terhadap rasa daging. Nilai rata-rata rasa daging ayam kampong Broiler matang memiliki rata-rata score sebesar 2, 41 berarti tingkat kesukaan panelis akan rasa daging ayam persilangan kampung broiler 
matang masih pada daerah suka. Pendapat Yudistira 2005, yang menentukan rasa daging dan daging yang berkualitas baik mempunyai rasa relative suka. Rasa makanan dapat dikenali dan dibedakan oleh kuncup-kuncup cecapan yang terletak pada yaitu noda merah jingga pada lidah (Winarno 2002).

\section{KESIMPULAN}

Berdasarkan hasil penelitian dapat disimpulkan bahwa Hasil pengujian organoleptik hedonik dan mutu hedonik terhadap persilangan ayam kampung broiler dengan kepadatan kandang yang berbeda, perlakuan masih berada pada kisaran score 3 .

\section{DAFTAR PUSTAKA}

Daryono BS, Satriya R, Rohmah Z, Erwanto Y. 2012. Penguatan Industri Bibit Unggas Nasional melalui Produksi Indukan Gama Ayam Lokal Unggul.Jurnal IImu Pengetahuan dan Teknologi Tepat Guna. $1(2)$ : 2089-2721.

Hafid, H, dan Rugayah, N. 2009. Persentase Karkas Sapi Bali pada Berbagai Berat Badan dan Lama Pemuasaan Sebelum Dipotong. Seminar Nasional Teknologi Peternakan dan Veteriner.

Lawrie, R.A. 2003. IImu Daging edisi ke-5. Penterjemah Aminudin Parrakasi.Universitas Indonesia. Jakarta.

Lyon, BG, Smith DP, Lyon CE, Savage EM. 2004. Effects of diet and feed with drawal on the sensory descriptive and instrumental profiles of broiler breast fillets. Poultry Science. 83(2):275-281

Manoppo, M.R.A., et al. 2007. Pengaruh Pemberian Crude Chlorella Terhadap Kadar Total Kolesterol Darah Ayam Broiler. Fakultas Kedoketran Hewan, Universitas Airlangga. Jurnal IImiah Peternakan 1(1):314-322

Northcutt, J.K. 2009. Factors Affecting Poultry Meat Quality. The University of GeorgiaCooperative Extension ServiceCollege ofAgricultural and Environmental Sciences-Departement of Poultry Science (Bulletin1157). Pub. : 12/01/2009. Soeparno, 2009

Nurwantoro dan Mulyani S. 200 3. Buku Ajar Dasar Teknologi Hasil Ternak. Universitas Diponegoro. Semarang.
Soeparno. 2009. Ilmu dan Teknologi Daging, cetakan II. Fakultas Peternakan UniversitaGadjah Mada. Yogyakarta.

Walpole RE. 1990. Pengantar Statistika. Jakarta (ID) : PT. Gramedia Pustaka Utama.

Warris. 2000. Meat science an introductory text. CABI Publishing, Bristol.

Winarno FG. 2002. Kimia pangan dan gizi. Gramedia Pustaka Utama, Jakarta.

Yusniar, L dan Nilasari. 2009. Biar daging ayam tidak berkolesterol tinggi. http://www.majalahtrust.com/bisnis/pelua ng/248.php. 